DOI https://doi.org/10.18551/rjoas.2017-06.11

\title{
POLICY IMPLEMENTATION OF MASTERPLAN E-GOVERNMENT AT ADMINISTRATIVE VILLAGES IN PROBOLINGGO
}

\author{
Wahyudi Achmad Gani*, Abdul Juli Andi, Rochmah Siti \\ Department of Public Administration, Faculty of Administrative Science, \\ University of Brawijaya, Indonesia \\ *E-mail: wahyudiaset@gmail.com
}

\begin{abstract}
In order to realize good governance, public service execution is a primary indicator in assessing local government performance. To increase the quality of local government service, it needs to be accentuated facilities, efficiency, and effectiveness principle so the community can easily get a quality service. One of elements of public service quality improvement is the implementation of information technology-based E-Government. This study aims to describe and analyze policy implementation of Masterplan E-Government and supporting and barrier factors of E-Government implementation at administration villages in Probolinggo. This focuses on (1) Masterplan e-Government implementation in Probolinggo and (2) supporting and barrier factors in the E-government implementation in Probolinggo. The result shows that Masterplan implementation has been running on in Probolinggo including at an administration village with the supporting an barrier factors in its implementation.
\end{abstract}

\section{KEY WORDS}

Policy, implementation, masterplan, e-government.

Democracy and local autonomy establishment bring changes and claims on the government to always be able to answer a dare related to the public service. Through the improvement of public service and community participation empowerment, local government is expected able to increase creativity, innovation and with its commitment tries to improve the quality of public service. In order to realize good governance, public service execution is a primary indicator in assessing local government performance. One of elements of public service quality improvement is the implementation of information technology-based $\mathrm{E}$ Government.

Information technology as an equipment in performing public service is right now needs and demands in each government agency giving public service. The purposes of EGovernment-based service are the determination of time and low cost in its performance. EGovernment performance in Probolinggo is actually started by being issued Presidential Instruction (Inpres) No. 3/2003 concerning National Policy on E-Government Development. After being issued the Inpres, Probolinggo government has been running its implementation. A number of efforts has been done in order to perform E-Government in Probolinggo like providing more network connectivity. But then information technology development related to the application and network provision to support Local government Organization (OPD) service performance is not maximal yet.

In 2010, Probolinggo government issued the Probolinggo Mayor Regulation No. 35/2010 on Masterplan E-Government in 2010-2029 as an effort to performance acceleration of E-Government with information technology development. This regulation is expected to encourage E-Government performance acceleration in providing public service. The same goes for the condition of Masterplan E-Government implementation supporting public service performance at administrative village level. An Administrative village as a unit of organization under the sub district or part of it has strategic positions and functions in performing public service executed by Probolinggo government. A lot of barriers faced by administrative village in executing Masterplan E-Government has to become a concern from Probolinggo government. Those barriers are a low means of support, there is no integrated data yet in the 
integrated system and infrastructure at an administrative village which is not up to standard both software and hardware. Moreover, the executors are not suitable with the competency needed and there is not yet budgetary policy focused on the maintenance of information technology system that supports service in an administrative village.

\section{METHODS OF RESEARCH}

Perspective used in this research is qualitative descriptive research. This means to illustrate and dig into the facts that are not revealed yet along this time that is then explained and applied so known the real illustration. According to Patton (1980: 303) a case data (qualitative) is consisted of all information about the case owned by someone.

Description is an objective representation of captured phenomenon. This research focuses on (1) Policy implementation of Probolinggo related to the Masterplan Egovernment. The researchers try to see the policy implementation carried out is suitable with the Probolinggo Mayor regulation No. 35/2010 on Master plan e-Government in 2010-2019. Description and Analysis uses policy implementation model of Edward III, at which seen from the variable (a). An effective communication b) Sources (having been seen from strategic plans of district service units (Renstra SKPD), main duties and functions (Tupoksi) and cooperating with private sector); c) Disposition/executing agent attitude and d) bureaucratic structure (programs and activities performed), (2) supporting and barrier factors in the implementation.

This study was conducted at Information and Communications Agency, Kedungasem Administrative Village, Kedungasem Subdistrict Probolinggo and Curahgrinting Administrative Village Kanigaran Subdistrict Probolinggo. Type of data used are primary data which might take form of individual respondent and focus group, in addition internet can also be a data resource if the questionnaire is spread through internet (Uma Sekaran,2011) and secondary data from company's note or documentation, government publicity, industrial analysis from media, website, internet and etc. (Uma Sekaran, 2011). The data are collected from informant, social condition or circumstances and related document.

Data collection techniques used are deep interview, observation, documentation. To decide trustworthiness is needed data checking methods based on the several criteria. According to bachri (2010:55) there are four kinds of criteria, namely (1) credibility, performed by a) observational studies; b) improving persistence; c) Triangulation and d) references, (2) transferability, (3) dependability and (4) confirm ability. Data analysis techniques in this study consisted of data collection, condensation, data presentation, and conclusion by Miles and Huberman's model

\section{RESULTS AND DISCUSSION}

Policy Implementation of Masterplan E-Government in Probolinggo. Masterplan E-Government performance in Probolinggo is being performed based on the probolinggo Mayor Regulation No.35/2010. Variable used in this implementation process is accordance with the implementation model of Edward III, they are as follows.

Communication. Communication is a process of delivering information from communicator to communicant. This is related to the substance of the policy that has to be implemented. Policy information needs to be delivered to the policy executing agent to make his/him know, understand what becomes content, goal, direction, target group so the policy executing agent can prepare correctly what has to prepare and do to perform public service so that the result is like what expected. Communication performed may take form of consultation or coordination meeting. It has been running by Probolinggo Communication and Information agency, but consultation and coordination executed is not performed yet. It causes since the subordinates cannot perform yet commandments and clues delivered by the supervisor. In addition, the leader often misses coordination meeting so the strategic decision in the Masterplan E-Government cannot be made. Commitment is truly important in the implementation of appointed policy. 
Resources. Such a resource is the authority owned by Communication and Information agency. It is related to the renstra, tupoksi, and cooperation with private sector. There have been contents in the Renstra arranged of a implementation framework of Masterplan EGovernment policy in Probolinggo. However, it needs reinforcements on a field directly handling the implementation of Masterplan E-government, so that in the future budgetary plans, activity and program can be arranged with the needs in the E-Government development framework. For that reason strategy and well-arranged target is needed. Strategy that has been there in the renstra of Communication and information agency should be able to implement in order to overcome barriers in the implementation of Masterplan eGovernment. For that reason, management in performing arranged Renstra is needed so can be realized purpose and target of policy especially in term of implementing Masterplan eGovernment.

Determination of jobs and responsibilities (called as "tupoksi") of a unit of organization becomes legal framework of the organization itself in performing activity and at the same time is as the warning signs in the performance of duties and coordination of an application at field. Tupoksi has been performing by Communication and Information agency, but not all related to the implementation of Masterplan E-Government can be performed in the program and activity. This is much influenced by several factors in the process of planning and budgetary ceiling. For that reason, performance of main duties and functions in an organizational chart has to be realized into activity that will help organization reaches vision, mission, goal and target has been decided. While in its authority to perform cooperation with private sector in order to Masterplan E-Government acceleration, Communication and Information agency has performed strategic cooperation with PT.INDOSAT Tbk. Yet, the cooperation was just started at the end of 2016, so that cooperation with private sector in term of accelerating Masterplan E-Government performance is performed after waiting for 6 years and evaluation cannot be performed yet since the cooperation runs less than one year.

Disposition/Attitude. Personnel positive attitude performing activity in term of implementing masterplan E-Government extremely helps in performing duties. This positive attitude is formed through staff meeting held routinely and group discussion held in order to find a solution. However, high work motivation cooperation among personnel has to be balanced by giving reward to the personnel of high performance so positive attitude can be kept up.

Organizational Chart. The result discussed above shows that organizational chart related to the program and activity performed in term of implementing Masterplan eGovernment policy. With the organizational chart owned, programs and activities executed in term of implementation have been carried out from 2013 until 2016. Probolinggo local budget is getting increase, this shows commitment and consistency of probolinggo government in implementing Masterplan e-Government. However, it needs a program evaluation and performance-based activity.

Supporting and Barrier Factors in Implementing Masterplan E-Government Policy. In this research, supporting factor of Masterplan E-Government implementation is the existence of an institution specially performs Masterplan E-government implementation at administrative village namely Communication and Information agency. This is important since through the institution or organization, duties or function to develop E-Government at administrative villages in probolinggo can be handled. Institutional existence factor playing role as an executing agent in the implementation of a policy gives an important meaning since through the institutional specially performing particular function will accelerate the process of goal achievement from appointed policy. Barrier factors consisted of:

Inadequate facilities and infrastructure. This factor includes network used in the connectivity is not maximal enough, while the equipment used on information system-based service is not accordance with needed specification. It needs a discourse related to the network while considering areal typology and document arrangement of expenditure plan and maintenance plan.

Inadequate human resources. From the quality and quantity side, the existence of human resources is inadequate. It must have a base location system and administrative 
village's employment transfer managed well. The existence system does not take administrative village side yet so the administrative villages' personnel are able to run its function in providing service to the community. Supervision to the administrative village's personnel also needs to do periodically through technical mentoring session (Bimtek) and education and training (Diklat).

Inadequate Budgetary. Having position under the subdistrict, administrative village budget is a part of sadistic budget and it is only office and operations budget. There is no technical and synergies budget with program and activity budget of technical agencies. Adequate budget allocation will help administrative village in performing public service function-based information technology development. It needs a policy related to the existing budget in the administrative village, so that it can synergize with technical agencies in the implementation of E-Government Masterplan policy.

\section{CONCLUSION AND SUGGESTIONS}

Based on the research, it can be concluded as follows:

Policy implementation of Masterplan E-Government at administrative village has been performing if seen from the existing focus: effective communication, sources available, disposition or attitude and organizational chart. But then in the performing stage it is not maximal yet. Several reasons are communication performed cannot be followed up by subordinates, the lack of commitment, vision/mission related is not all performed, cooperation carried out is not maximal yet, there is no clear reward system yet to the personnel of high achievement, program and activity executed is evaluated based on the performance.

Communication and Information agency is the organization which executes Masterplan E-Government performance. A lot of factors who becomes barrier in the implementation of Masterplan E-Government policy at administrative village level are facilities and infrastructure, which are not supported yet, the lack of quality and the number of human resources, and there is no budgetary support.

This program needs network mapping document, synchronization and synergy of program and activity, evaluating and monitoring program and activity periodically, discourse on areal typology-based network, human resources planning at administrative villages and budgetary planning took administrative village side.

\section{REFERENCES}

1. Bachri, B.S. 2010. Meyakinkan Validitas Data Melalui Triangulasi pada

2. Penelitian Kualitatif. Surabaya: Universitas Negri Surabaya.

3. Edward III, G.C. 1980. Implementing Public Policy. Congressional Quarterly Press. Washington DC.

4. Patton, M.Q. 1980. Qualitative Evaluation Methods. Baverly Hills London: Sage Publications.

5. Sekaran, U. 2011. Metode Pemelitian untuk Bisnis, Jakarta: Salemba Empat. 